Article

\title{
Johann Scheffler (Angelus Silesius): The Silesian Mystic as a Boethian Thinker. Universal Insights, Ancient Wisdom, and Baroque Perspectives
}

\author{
Albrecht Classen (D) \\ Department of German Studies, University of Arizona, Tucson, AZ 85721, USA; aclassen@email.arizona.edu
}

Received: 19 October 2018; Accepted: 29 November 2018; Published: 4 December 2018

\begin{abstract}
This paper offers an analysis of a number of the fascinating, thought-provoking, and yet often deeply puzzling epigrams by the German Baroque poet Johann Scheffler (Angelus Silesius), and illustrates how his enigmatic mystical concepts were influenced, to some extent, by the philosophical thoughts offered by the late antique statesman and thinker Boethius (d. 525). While recent research has already reached new insights into the long-term reception history of Boethius's De consolatione philosophiae well into the modern age, including by Scheffler, we still face the critical desideratum to determine the meaning of Scheffler's spiritual insights in direct correlation with Boethius's fundamental teachings, and hence, to answer the intriguing and challenging question of why Scheffler, along with Boethius, continues to speak to us today, and this perhaps more than ever before. Even though Scheffler pursued deeply religious questions typical of his time, he obviously greatly profited from Boethius's musings about the meaning of the absolute Goodness, the vagaries of fortune, and the instability of all material existence in the quest for happiness. Many times we observe that Scheffler offers paradoxical and also apophatic statements, but those make surprisingly astounding sense if we read them, especially in light of Boethius's teachings, as perceived in the seventeenth century. The epigrams thus prove to be the prolific outcome of universal cross-fertilizations and demonstrate the continued impact of antiquity on the modern world and the growing need today to accept the notion of "world literature" not only in a contemporary, transcultural perspectives, but also in terms of universal interactions throughout time.
\end{abstract}

Keywords: Johann Scheffler (Angelus Silesius); Boethius; epigrams; mysticism; reception history; Baroque literature; quest for happiness; quest for the Godhead

There are certain moments in the history of literature, philosophy, the arts, and music when serendipity brings together voices from the past and from the present, and allows them, in the process of interaction, to reach new insights into the essence of all existence through a trans-chronological dialog. In fact, poets have always and repeatedly addressed very few issues, continuously reflecting on responding to the insights developed by their precursors (Weisstein 1973; Borsò and Schahadat 2019), and have thus contributed to the same universal examination of the quest for God, the answers regarding the meaning of death, the purpose of life and its value, that is, life per se in a constant exchange of ideas from throughout time (Auerbach 1953/1968; Curtius 1989/1990; Beecroft 2015).

To rephrase a fundamental understanding of the literary process all by itself, at closer analysis, we can observe the most intriguing moments in the history of literature when individual writers ingeniously succeeded in drawing from past thinkers in order to formulate the same universal ideas in their own respective language and imagery by means of mystical inspirations or rather philosophical instructions. Through the reception of ideas from the past, the new world could gain a new impetus and move forward. Such epiphanic and transformative moments have happened all over the world throughout times, occasionally leading to the creation of a new religion (Judaism, Christianity, and 
Islam), or to the establishment of new works of art and literature relevant for people in various cultures, and which thus managed to speak to humanity at large.

In this paper, I suggest that such a transformative moment occurred when the Baroque poet Johann Scheffler translated/adapted, in a very creative way, the philosophical ideas developed by Boethius (d. 525; Boethius 2005; Boethius 2001), about the individual's quest for universal happiness in his epigrams contained in his Cherubinische Wandersmann (1657). There might also be some ideas that he could have borrowed from the ancient tradition determined by Plato and Aristotle, but the arguments developed by Boethius seem to reappear in most striking similarity in Scheffler's epigrams.

The creation of the literary myth of King Arthur, especially by Chrétien de Troyes; the emergence of the theme of the glorious but hopeless love between Tristan and Isolde (Gottfried von Straßburg); the quest for the Grail (Wolfram von Eschenbach); the admirable pursuit of honor in the heroic world (El Poema de Mîo Cid); the dream of a utopian world (Thomas More); or the projection of the entertaining but futile efforts by Don Quixote (Miguel de Cervantes) represent highlights of this phenomenon in the pre-modern world. Even if these reflections seem to borrow much from Romantic perspectives, as formulated by August Wilhelm Schlegel in his Berlin University lectures in 1802, and by Johann Wolfgang von Goethe in his conversations with Eckermann on 1 January 1827 (Vipper 1985; Prendergast 2004; Tötösy de Zepetnek and Mukherjee 2013; Damrosch 2017; Fang 2018; Bassnett 2019; etc.), they certainly help us today to grasp more universal perspectives of great relevance in our modern world, by understanding the continuous impact of ancient, medieval, and early modern ideas on our own. There is no doubt that we can call literature, above all, a multivocal discourse, a phenomenon consisting of an infinitude of connections between past and present, outside and inside, and between self and other. At the risk of stating the obvious, every literary analysis requires a horizontal (present) and a vertical perspective (past), and only if we incorporate the chorus of historical and contemporary sources, can we hope to gain an in-depth understanding of our objects of inquiry (Eickelmann and Friedrich 2013; Gramling 2016).

We can observe this intriguing but rare phenomenon, subtly but meaningfully in the epigrams by the Silesian writer Johannes Scheffler, also known under his pseudonym Angelus Silesius (The Silesian Angel) (1624-1677). He was a major German Baroque poet who exerted tremendous influence on his posterity, especially because of these concisely formulated poetic statements (two to four, rarely five or six, verses only) that address the ultimate quest for meaning and spiritual enlightenment. Those extremely short poetic statements have reverberated throughout time and far beyond the German-speaking world, and are available not only in modern editions, but also in various translations.

The epigram was one of the most favored poetic genres in the seventeenth century, and Scheffler proves to be a true master of it (Weisz 1979; Hess 1989). Mystically influenced and deeply informed by medieval religious thought and also late-antique philosophy, Scheffler proves to be a most powerful poet whose works continue to speak, I would argue, to the present generation in spiritual and aesthetic terms, once we have carefully analyzed and discussed them in their proper cultural-historical context (Hoffmann 2008). The combination of opaque with crystal-clear statements within an epigram; the combination of philosophical, ethical, religious, and moral reflections in the shortest space possible; and the boldness to state observations that go so radically against common rational thought, all prove to reflect Scheffler's timeless value as a Baroque poet.

In fact, as this paper wants to claim, here, we find some of the best early modern examples of German poetry, deeply influenced by mysticism, but also by the ideas formulated by the late antique Roman philosopher and statesman, Boethius (d. 525). At the same time, which I can only touch on in passing, Scheffler exerted a tremendous influence across modern German and European literature and philosophy, but this does not mean that scholarship has paid sufficient attention to his glorious epigrams, which might represent some of the best verse statements produced in the history of German literature.

This poet hailed from Breslau in Silesia (today Wrocław in Poland) and indirectly witnessed the horrors of the Thirty Years' War ravaging Germany from 1618 to 1648. Nevertheless, like his 
contemporary Andreas Gryphius (1616-1664), he enjoyed a solid humanistic education and later studied at the universities of Strasbourg and Leiden, focusing particularly on medicine-again parallel to Gryphius, who stayed in Leiden until 1644, the same year that Scheffler arrived there to take up his studies. Apart from many tracts, religious reflections, and treatises, Scheffler gained fame for his epigrammatic poems, first published in 1657 in Breslau as Heilige Seelen-Lust oder Geistliche Hirten-Lieder, der in ihren Jesum verliebten Psyche (Holy Joy of the Soul, or, Spiritual Pastorals of Psyche Who Is in Love with Her Jesus). Although highly unorthodox in its spiritual orientation, this anthology quickly experienced significant popularity, and ultimately appeared in a second edition in 1668 .

Another volume followed soon, Geistreiche Sinn- und Schlussreime (Ingenious Epigrams and Apothegms), which he also published in 1657, but this one in Vienna; because of the problematic nature of some of his statements that were certainly highly unorthodox, both for the Protestant and the Catholic Church. Again, Scheffler was very successful and could publish a second edition already in the same year in 1657, when he gave it the title by which it is known to us today, namely: Cherubinischer Wandersmann oder Geist-Reiche Sinn- und Schluß Reime zur Göttlichen beschauligkeit anleitende (Cherubinic Wanderer; or, Ingenious Epigrams and Apothegms Conducive to Divine Contemplation) (Eilert 1936; Reichert 1967; Hoffmann 2008; Von Kralik 2013). In 1675, he edited this collection for a second time, and published several other religious works (Sammons 1996).

Scheffler converted to Catholicism in 1653, and was subsequently appointed Imperial Court Physician to Ferdinand III, the Holy Roman Emperor (1654), probably because the Catholic Church wanted to provide him with an official status, and thus with protection against attacks by Protestant authorities and other theological critics. Although we do not know in full detail what public role he assumed in the following years, whether he joined the Order of the Franciscans or even the Jesuits (both rather doubtful), we can be certain that he contributed significantly to the reintroduction of Catholic rituals and processions in Breslau, and hence in Silesia at large, such as the procession on the day of Corpus Christi, on 8 June 1662.

At the same time, Scheffler experienced much public animosity and was heavily criticized by his opponents, whenever an opportunity arose, especially because he seemed to have turned in his old age to rather abstruse concepts about how to deal with heretics in a most brutal fashion, if those accusations by his contemporaries can be proven. He died on 9 July 1677 in a Jesuit house in Breslau, leaving behind an influential body of epigrams and polemics. But he himself had declared that he was not a Jesuit and did not see himself leaning toward any particular monastic order (Held 1952, vol. 1, pp. 18-60).

Scheffler relied heavily on the epigram, which had become a favorite poetic form in the Baroque period, drawing both from classical antiquity (Martial; see Holzberg 2012) and contemporary neo-Latin poetry by John Owen (1560-1622), which was translated into German in 1653, the very year when Scheffler fully embraced Catholicism (Schmidt 1986, p. 12; Flitch 1932, pp. 17-64).

Traditionally, scholars have mostly endeavored to identify the specific connections between Scheffler's epigrams and contemporary church songs, poetry, and the tradition of medieval mysticism (Hildegard von Bingen, Mechthild von Magdeburg, Meister Eckhart, Heinrich Seuse, and Johannes Tauler, e.g., as well as late medieval philosophy (Nicholas of Cusa). Held also points out such sources as Scheffler's friend Abraham von Franckenberg, then Georgette de Montenay; Daniel Sudermann; and Daniel von Czepko. In turn, Scheffler enjoyed considerable respect in the following centuries, as outlined by Held, who traces some lines of reception in the works of the poet Gerhard Tersteegen (1697-1769), the philosopher Gottfried Wilhelm Leibniz (1646-1716), the biographer and cultural critic Karl August Varnhagen von Ense (1785-1858), the Romantic philosopher Friedrich Schlegel (1772-1829), the poet Friedrich Rückert (1788-1866), the Magical-Realist poet Annette von Droste-Hülshoff (1797-1848), the Swiss poet Gottfried Keller (1819-1890), and many others (Held 1952, vol. 1, pp. 81-85). It is also possible to confirm that Martin Heidegger (1889-1976) responded with great enthusiasm to Scheffler's paradoxical epigrams in his university lecture "Der Satz vom Grund" (Freiburg, Winter semester 1955/1956; first published in 1956) (Stenger 1990, pp. 155-62), while Karl 
Jaspers referred to him in his essay "Der philosophische Glaube angesichts der Offenbarung" (1948; The Philosophical Faith in Face of Revelation) (Schweitzer 1992).

Whether Scheffler was also familiar with a broader philosophical discourse beyond his religious frame of mind, whether he might have been influenced by religious inspirations from the East (Zen Buddhism), for instance, particularly because of numerous striking parallels, cannot be determined here and would also be highly questionable (Egawa 1992). By contrast, the purpose of this study is decidedly not to pursue a positivistic perspective or to give way to speculation regarding heretofore a possibly ignored Asian influence (cf. Franck 2005). Serendipity, however, makes it possible for us to recognize, above all, striking parallels with Boethian ideas as expressed in the De consolatione philosophiae (ca. 525 C.E.). In a previous study, I have demonstrated that Boethius's famous treatise was well known also in the seventeenth century, and belonged to the standard school textbooks, which strongly suggests that Scheffler was also thoroughly familiar with it after he had completed his university studies (Classen 2018; Kaylor and Phillips 2012; see also below). The critical question thus emerges as to what extent the philosophical ideas as expressed by Boethius might have found their way into the epigrams of this Baroque mystical poet.

At first, if we consider the major themes pursued by Scheffler, those parallels might seem to be a bit speculative. According to Sammons (1967), the epigrams address primarily the quest for God (57), the relationship between the self and God (66), the meaning of eternity (79), and the relevance of death (88), all of which suggests that he closely followed the biblical text, and not Boethius. Georg Stenger has discriminated the range of the themes employed by Scheffler considerably further, and has developed an entire phenomenology of the apophatic in the Cherubinische Wandersmann (1990), isolating and describing topics such as lightning, the presence of God in the human soul, birth, poetic creativity, vision, the heart, love, and the role of the rose as a universal icon. The central issue, however, consists of the universal quest for meaning, for the answer about the relevance of human life and its relationship with the Godhead. In other words, Scheffler really developed, although in an often rather fragmentary fashion, a new or a very old epistemology that drew not only from late medieval theology and mysticism, but also from Boethian thinking about the essence of goodness, and hence of the meaning of human existence.

Let us begin with the analysis of some of those epigrams in which we regularly recognize intellectual challenges of the highest caliber, combining religion with philosophy. We cannot simply fall back to the generic assumptions often voiced (Held; Sammons; Stenger) and be content with the observation that here, we come across the culmination of the mystical discourse, reaching Scheffler in the seventeenth century, originating in Mechthild von Magdeburg (ca. 1207-ca. 1294), Meister Eckhart (1260-1328), and Johannes Tauler (ca. 1300-1361), transmitted via Jakob Böhme (1575-1624) and others, as relevant, as those sources certainly prove to have been for our Baroque poet. Instead, Scheffler composed his epigrams in such a highly subtle, philosophizing manner that they force us to search for other sources of inspiration as well, especially Boethius's fundamental treatise about the proper approaches to the quest for true happiness. The latter offered powerful, highly influential ideas about the working of Fortune, the need to search for true happiness, and about the ultimate properties of Goodness, which totally supersedes all evilness, imprisoned in the material dimensions (Boethius 2001, Consolation of Philosophy, trans., with introduction and notes by Joel C. Relihan; Boethius 1976, De consolatione philosophiae). Even though Scheffler does not include any explicit references to any of his sources, and hence does not mention Boethius's name either, we can be certain that he studied him at school or at the university, and acknowledged him, as was the common standard of advanced education well into the eighteenth century and beyond, as one of the central cornerstones of all post-classical philosophy. The future poet received his Ph.D. in philosophy and medicine from the University of Padua on 9 July 1648 , but before, he had already studied briefly at the University of Strassburg and then for two years at the University of Leiden (Held 1952, vol. 1, pp. 22-23). In the subsequent years, he was deeply influenced by Valentin Weigel, who in turn was a great enthusiast of Boethius, as documented by his own Boethian treatise (Held 1952, vol. 1, p. 24; Classen 2019). 
There would not be any need here to summarize the central points of Boethius once again (Gibson 1981; McInerny 1992), and it should suffice for our purposes to understand that the prisoner Boethius learned from Philosophy that none of the traditional criteria that would lead to worldly happiness could really achieve that goal. Realizing that Fortune rules the world represents the first step in the treatise toward moving away from its wheel, and turning to the absolute Goodness, which is free of all contingency and is completely independent. Consequently, as we can read, for instance, in Book III, Prose 11, "this goal is what is longed for by all things, and because we have deduced that this thing is the good, we must admit that the Good is the goal of all things" (p. 83). Boethius offers, through Philosophy, many other definitions, but they all come down to the overarching understanding that "[ $t$ ]his thing, whatever it is-by which the things that have been established both remain unchanged and are set in motion-using the word that everyone habitually uses, I call God" (Book III, Prose 12, p. 85). This, ultimately, means that there is no real evil, despite the presence of evil people, who in the end eliminate themselves, because they do not follow the natural instinctual drive toward the Good.

One aspect in Scheffler's poems, however, needs to be considered before we turn to the epigrams themselves and the question as to what extent they reflect specific inspiration by Boethius. They do not represent a cohesive, logical arrangement of individual thoughts that create, step by step, a comprehensive philosophical-theological argument comparable to the elaboration by Boethius in his dialog narrative. Hence, we can, or probably must, rely on a somewhat random approach, as Scheffler engaged with his topic/s from many different perspectives, and constantly coined new images for the overarching concept behind the collective of epigrams (Kern 1866, p. 60; Spörri 1947, pp. 91-99; Althaus 1956, pp. 32-34; Huss and Nelting 2017). Then, I will concentrate on Scheffler's epigrams contained in Book II of his Cherubinische Wandersmann, not because they are necessarily better witnesses of the poet's responses to Boethius, but because they have received less attention in previous scholarship, and yet address, in one way or the other, the same fundamentally humanistic approach pursued by Scheffler, revealing equally mystical and philosophical influences in the universal quest for the absolute Godhead.

At first sight, an epigram such as "Das Äußere tröstet mich nicht" (no. 102; Angelus 1949; or Scheffler 1949) seems to speak a fairly simple religious language, connecting the individual with the Archangel Gabriel, whom the poetic voice wants to be a messenger also for him, connecting him with the Virgin Mary, "Was hilft michs, Gabriel, daß du Mariam grüßt, / Wenn du nicht auch bei mir derselbe Bote bist" (What good is it, Gabriel, that you are greeting Mary if you do not come to me as the same messenger?). The material exterior proves to be deceptive; only a spiritual form of communicating with the divine can promise to yield new light on the pathway pursued by the human being. Much more meaningful, however, seems to be the epigram "Die geistliche Geburt" (no. 103), in which we are told that once God's spirit, in its very essence, has touched an individual, then the "Kind der Ewigkeit" (child of eternity) will be born. Scheffler argued consistently, and yet constantly in different terms, to strive for the escape from the material condition being anchored in time and space and to aim for the ineffable existence. This also entails, following the epigram, that God's spirit can and does reach out to the human creature, and fill it with a sense of God's being. The poet then goes one step further and claims that when one's own soul has been transformed into a "Magd" (no. 104; maid), then pregnancy will occur, parallel to the Virgin's immaculate conception.

In order to welcome God into one's own world, the heart needs to be expanded to make room for God. Scheffler appeals to his audience to turn themselves into God's own "Himmelreich" (no. 106; heavenly kingdom), because God wants to be our king, or rule over us. All of this requires, however, to strive for being a new birth "mit Wesen" (no. 107; with essence), otherwise the union with Christ would not be possible, "Hat deine Neugeburt mit Wesen nichts gemein / Wie kann sie ein Geschöpf in Christo Jesu sein?" (If your new birth is not associated with essence, how can it then be a creation by Jesus Christ?). The poet does not suggest that the world in its materiality is going to dissipate; on the contrary, it will continue to be in its physical manifestation, but God's appearance makes possible the destruction of all obscurity (no. 109). Ultimately, which Scheffler expresses many times in constant 
modifications of the same idea, the human entity will reach out to God, and find Him, once the human body has been transformed from being a crude material object into a sparkling jewel (no. 110). For the truly illuminated individual, all that matters would be to be born in God and to bring God to life again (no. 112). As much as many creatures in this world seem to represent a danger to people, they all turn out to be vehicles to free the soul from the body, and to take the spiritual being onto the pathway to God (no. 114). All of this means that Scheffler coins poetic images for the reader/listener, through which the individual should be able to comprehend that the path toward full (religious) enlightenment takes the individual out of the material existence into an essentially idealistic world, where the Godhead rests, and this in a striking parallel, both with much mystical thought, biblical teaching and also the Boethian teachings that were widespread in seventeenth-century university lectures, as the many new editions and translations confirm (see below).

In order to achieve the goal of finding the right path, the individual ought to put one's mouth directly at the spigot of a barrel and drink from it, that is, to search for the source of all original thought (no. 113). Social interaction would normally lead the person astray in his/her quest for God; only the company with a child, a virgin, a dove, and a lamb, all symbols of innocence and freedom from sin, could be tolerated (no. 116). A truly pious person would resemble God in the degree to which $\mathrm{s} /$ he would be able to observe complete tranquility, leading over to a dimension beyond time and space (no. 119). Hence, the ultimate goal would be, as Scheffel does not tire to reiterate, to join with God and to become one with Him (no. 120). To illustrate this phenomenon, he equates himself with the grapevine, planted and watered by God the Father, while the fruit that grows from the plant, the grape itself, constitutes the Holy Spirit (no. 122). In order to achieve the goal of being one with God, "Muß Gottes Wesenheit in dir sein angeglommen" (no. 125, 2; God's essence must be glued into you). Wherever we turn, Scheffler emphasizes the supreme importance of distancing oneself from the material existence and of following the path to a higher entity where happiness and goodness rest. The best condition of human life would be to enjoy freedom from all material possessions (no. 127), which carries many echoes from the biblical text, and would also resonate in many other religions.

Most importantly, however, at least in the case of Scheffler, appears to be, apart from the mystical tradition, Boethius's teachings that rely on virtually the same terms and pursue the same epistemological directions, although they are certainly not informed by mystical inspiration. The two epigrams, no. 132 and no. 133, underscore this observation most poignantly, because here, the poet suggests that God's property is to flow into the soul of all living beings, which requires that the individual dismisses all possessions, all will, and even all knowledge (no. 132): "Was ist Gotts Eigenschaft? Sich ins Geschöpf ergießen, / Allzeit derselbe sein; nichts haben wollen, wissen" (What is God's property? To flow into the created being; to be the same all the time, not to want anything, to know). Instead of aiming directly for paradise, the individual should pursue "Gelassenheit" (no. 133), the readiness to let everything go and to relax in the presence of God. In the epigram "Die Gelassenheit" (no. 135; same title), he dismisses strength, power, arts, wisdom, wealth, and pretense in favor of being the father's, or God's, child (Gebert 2012), “Freund, glaub es, heißt mich Gott nicht in den Himmel gehn / So will ich lieber hier auch in der Hölle stehn" (Friend, believe me, if God does not command me to go to heaven, I will rather stay here in hell). As much as this would represent a deeply Christian ideal, as much we also observe the central Boethian notion of not pursuing happiness in worldly matters, as we can read in De consolatione, "it is clear that true happiness alone is the thing that is desired ... there is no other thing that is equally capable of bringing about true happiness than a state replete with all good things which does not need any outside thing but is sufficient unto itself" (Book III, Prose 2, 52). When Scheffler claims that only "Vernichtigkeit" (no. 140, 1; actively becoming nothing) leads us toward true happiness, because only this would contribute to the overarching effort to gain more of "Göttlichkeit" (2; divinity), he is getting very close to Boethius's own formulations, and particularly to his basic ideas, as much as those are primarily philosophical in kind, "all things seek the Good; or you may in fact define the Good this way, as that which is desired by all things" (Book III, Prose 11, 82). 
Insofar as the latter consistently argued against any reliance on Fortune and emphasized the need to free oneself from the forces of that world system (contingency), Scheffler could only agree with him when he composed his epigram "Der Grundgelassene" (no. 141), as follows: "Ein grundgelassner Mensch ist ewig frei und ein; / Kann auch ein Unterschied an ihm und Gotte sein?" (A person fundamentally free from all care will be eternally free and one; so could there be any difference between it and God?). Only the one who would be fundamentally detached from the material sources of happiness would come closest to God. However, Scheffler also admits that he himself could not answer convincingly what the true nature or the identity of God would be; he can only express it with the term "Überwesenheit" (no. 145, 2; being beyond all essence). The absolute freedom from the wheel of Fortune (Boethius) can be found in the merging with Christ (no. 151), and in the inner liberation from all wishes. Only those who would not be moved by material conditions could free themselves from contingency and move into the world of the absolute goodness (no. 151) or happiness, as Boethius also formulated it many times. This idea also inspired Scheffler to reflect upon the question regarding the meaning of time and eternity, concluding with a purely negative response, "Nicht Nun, nicht Ichts, nicht Nichts, sie ist, ich weiß nicht was" (no. 153, 2; Not now, not I, not nothing, it is, I do not know what), again, as we can certainly conclude, in close conformity with Boethius's teachings regarding the relationship between Providence and Destiny, that is, God's role being both in the past and the present at the same time (Boethius, Book V).

The most critical point in Boethius's treatise, the one that vexed him the most throughout the text, both in personal and in philosophical terms, were questions of 'why there are evil people?', 'why does evil have so much power?', and 'how can goodness succeed in the long run in the face of all evil that is prevalent in daily life?'. As Philosophy then elucidates, evil people are simply blind to the universal goodness in them, and are so weak that they cannot even follow the natural path toward the good. Ultimately, they would eliminate themselves, like plants deliberately trying to grow where they cannot thrive, "there is no reason why you could in any way doubt that all the things that exist crave by their nature the permanence of remaining unchanged and by their nature avoid dissolution" (Book II, Prose 11, 82). Scheffler translates these ideas into religious concepts, and argues that, first, just one drop of Christ's blood would allow the faithful to become fully part of the Godhead (no. 165), and second, that evil has no essence, and that the blood of the symbolic sheep totally cleanses the individual from all evilness (no. 166).

Moreover, the liberation from the workings of Fortune, as Boethius outlined it, puts the individual on a path toward the Oneness with Goodness, a central idea that Scheffler formulates in his typically paradoxical fashion, "Ach ja! wär Ich im Du und Du im Ich ein Ein, / So möchte tausendmal der Himmel Himmel sein" (no. 179; Oh yes, if I were in You, and You in Me a union, then Heaven can be thousand times heaven). Sinners, or evil-doers, as Boethius would say, become victims of their own blindness, and entangle themselves ever more in their foolish self-centeredness (no. 181). Goodness, however, is all around us, or, as Scheffler formulates, God is omnipresent and beyond all time limitations (no. 182).

Most powerfully, Scheffler expresses his mystical vision of God being an essence all by itself, such as formulated in the epigram "Man mißt das Wesen nicht" (no. 188), as follows: "Es ist kein Anfang nicht, es ist auch nicht ein Ende, / Kein Mittelpunkt noch Kreis, wie ich mich immer wende" (There is no beginning and no end, / no center nor a circle, wherever I turn). For him, there is no beginning and no end, no center nor a circle defining the supreme being, because measurements are for physical entities, whereas God (Scheffler) or Goodness (Boethius) represent oneness, wholeness, unity, or power. Even though Scheffler pursued a definitely mystical discourse, we notice everywhere in his epigrams the direct influence of Boethian ideas and images, as well as words and expressions. After all, the Consolation of Philosophy enjoyed its timeless popularity not only because of the glorious logical development of his thought process regarding the workings of Fortune and misfortune, but also because of the drive toward the absolute entity of Goodness. As the comparison to Scheffler's epigrams indicates, there was apparently also a certain level of mystical perception in the treatise, taking the 
individual beyond the cold logic of the philosophical erudition into an apophatic dimension, which was also fully conceivable for a devout convert to Catholicism such as Scheffler (Pierre Courcell 1967; Margaret Gibson 1981; Desiree Cremer 2015).

Previous scholarship has quite successfully searched for translations and re-editions of De Consolatione philosophiae as testimonies of the long life of Boethius's treatise in the Middle Ages and the early modern age (Kaylor and Phillips 2016). The addition of Scheffler's voice to this global chorus adds a new and significant dimension to this reception process, as elusive as his responses to Boethius might seem to be at first sight. Even though he never mentions the name of this famous philosopher, both his theological and philosophical explanations, if not his mystical perspectives, underscore unmistakably the considerable impact of the Consolation on his own thinking, and on that of his contemporaries (Classen, "Boethius and No End in Sight"). This also comes to the forefront in Scheffler's discussion of God's own properties, when he formulates that He is self-content (no. 190, 2), which proves to be virtually identical with Boethius's observation that Goodness, or the highest form of happiness, is defined by being free from contingency, or external desires and needs.

For the individual, this would then mean that no material condition in this world could provide any form of true happiness, as Scheffler insists in his epigram "Verleugnung seiner selbst" (no. 197; Denial of the Self). Nothing that people own would really be their personal property; everything actually belongs to God, which also appears to be deeply influenced by Boethian reflections. As mystical as it might be, when Scheffler notes that there is ultimately no difference between the self and God (no. 201), this finds a close parallel in Boethius's argument, that the good one would only reach freedom from Fortune if one leaves the material existence as a precondition of one's happiness, and turns to the free and independent entity of Goodness.

True happiness rests, according to Boethius, in the ability to search for it beyond the confines of Fortune, that is, in true goodness, which Scheffler specifies as the realization that the human being is nothing but "die Anderheit" (no. 201, 2; the Otherness) of God. At the same time, the critical challenge for all people would be to learn to differentiate between good and evil, certainly a fundamental religious charge (no. 205), but also an issue of great concern for Boethius, who suffered so deeply, because he was accused of state treason, and yet always claimed complete innocence. Those who pursue a balanced, calm, considerate, obedient, and rational lifestyle will be able, as the poet says in his epigram "Die vierfache Überwindung" (no. 214; The fourfold overcoming), to achieve happiness here on earth. While Boethius is constantly challenging Philosophy to give him more direction, and to explain the dialectics in all existence where evil seems to dominate; after all, Scheffler embraces an ethically advanced perspective driven by religious ideals.

When he expresses his deep concern about people's lack of satisfaction with their own lives, always aiming for more pleasures or gains, without finding themselves, such as in the epigram "Der innerliche Friede" (no. 239; The Internal Peace), Scheffler directly reflects on Boethius's teachings, transforming them into a religio-philosophical insight. Instead of aiming for glory, wealth, or power, as Philosophy had taught Boethius, the individual should look for being content with his/her own existence and strive for goodness, "Das muß, bei guter Treu, Fried über Friede sein" (v. 2; That must be, in true trust, peace above all peace). Of course, we could always claim that Scheffler, here and elsewhere, resorts primarily to religious, Christian generalities, and global wisdom, as formulated already in the Old and New Testament. The same, however, could also be argued regarding Boethius's De consolatione philosophiae, where universal truths are brought back to light and then channeled through a new critical analysis in order to regain the inner peace and happiness that the individual simply tends to lose out of sight. Both Boethius and Scheffler, however, transform those general statements into new philosophical insights, through which the quest for Goodness (summum bonum) or the Godhead (Christianity) can be resumed and pursued to a successful conclusion.

There are many other epigrams, especially in Book I, in which we can detect clear influences from Boethius, such as in "Der Zufall muß hinweg" (no. 274; Fortune must be dismissed). Scheffler urges his readers to consider the working of Fortune, which he calls 'happenstance' or 'chance', and then 
urges them to leave it all behind in order to gain access to the essence of all being, "Du mußt ganz wesentlich und gefärbet sein" (v. 2; you must be entirely essential and colored). Although he does not resort to the image of the wheel, the universal impact of its instability, or 'accident', clearly informs this two-liner. Similarly, in "Eins des andern Anfang und Ende" (no. 276; One being the beginning and end of the other), he realizes that God is the ultimate goal of all being, which requires that the individual accepts that it would be His beginning, "So weset er aus mir und ich vergeh in ihm" (v. 2; "then he exists out of me and I dissolve in Him"). In another context, we discover clear echoes of Boethian ideas when he insists that God can only be good, whereas evil rests only in people (no. 129). Consequently, as Boethius had formulated already, God is defined by His self-sufficiency, oneness, and power, which Scheffler translates, if that is the right word, into the epigram "Die Bloßheit ruht in Gott" (no. 130: "Wie selig ruht der Geist in des Geliebten Schoß, / Der Gotts und aller Ding und seiner selbst steht bloß"; How blissfully does the spirit rest in the lap of the beloved, who is free of God and of all things and of itself). God, however, as Scheffler also notes, reconnecting more closely with Boethius, does not make distinctions, as for Him, all is one and the same, and embraces the fly just as much as the human soul (no. 127).

For the individual reaching out and searching for absolute happiness, as Boethius insists, one must leave behind all material conditions and turn one's back on Fortune altogether. Scheffler apparently adopted this stance, combining it with his religious perspective, and insisted that the truly devout person would have to leave behind all knowledge, love, and possessions, that is, all earthly aspects, before he would be able to aim for the ultimate goodness / God (no. 24). But the individual cannot actively strive for God, which constitutes the poet's more mystical perspective, "Gott ist ein lauter Nichts, ihn rührt kein Nun noch Hier. / Je mehr du nach ihm greifst, je mehr entwird er dir" (no. 25; God is a pure Nothing; no now and here can move Him. / The more you reach out for Him, the more He evades you).

We might get the closest to Scheffler's innermost thoughts when we once more highlight his notion of "Gelassenheit" (no. 99), where we might also observe influences of the ideas formulated by Meister Eckhart (Moran 2013, pp. 687, 697; Hackett 2013). To let everything go, to not attach any real value to all material objects, to accept joy and sorrow in equal measures, makes it possible for the individual to move beyond the physical constraints and aim for the absolute goodness, as Boethius would have stated it (cf. Hess 2007, p. 447). There are countless other opportunities to analyze Scheffler's epigrams in a wide range of other contexts, highlighting biblical, philosophical, theological, and literary sources from antiquity and the Middle Ages.

But let us conclude here with some final thoughts that will also take us back to the poet's biography and the history of book publishing in the seventeenth century. While previous scholarship has been mostly content with drawing more or less direct lines of reception between late medieval mysticism and Johann Scheffler, we also have to take into consideration that the poet underwent a thorough university education and was thus undoubtedly exposed to theological and philosophical texts, elaborated on by his teachers and through his own studies. As we know by now, Boethius's treatise continued to enjoy tremendous popularity also in the seventeenth century, so we would be well advised to take keep in mind closely the extent to which Boethius appears to have influenced Scheffler in a variety of ways. His epigrams constitute some of the most sophisticated quasi-mystical reflections and have exerted, in their own terms, a profound influence on early modern and modern literature and philosophy. Insofar as we can now connect Scheffler's poems with Boethius's famous treatise with a high degree of probability, we have identified a powerful node of reception history, a bridge, so to speak, between late antiquity and the modern world of literature and philosophy.

Granted, Scheffler does not mention Boethius by name in any of his epigrams and does not discuss the Consolatio de philosophiae in specific terms, as far as I can tell, not having scoured the entire Scheffler archive. Yet, a comparative approach, a probing of numerous epigrams for traces of Boethian thinking, reveals a wealth of poetic statements that strongly encourage us, if not force us, to add Boethius's concepts about Fortune, Happiness, and Goodness/God as significant sources that appear 
to have influenced and inspired this Baroque poet. As Scheffler resorted to the genre of epigrams, he deliberately evaded any scholarly attempts from today to trace a logical, consistent, or cohesive thought pattern in his works. Instead, the principle of randomness dominates in his œuvre, which makes it difficult for us to reach completely solid conclusions. His language, as beautiful as it proves to be, reveals and obscures many of the different sources from which he certainly drew. Hence, I would have to grant that the deliberate opaqueness and mystical worldview of his epigrams makes it a challenge to argue entirely conclusively that the poet had studied Boethius and had embraced his fundamental ideas.

Nevertheless, the close analysis of a larger selection of his epigrams lends considerable weight to the claim that this thesis holds true, and can be pursued further for the interpretation of many other texts by Scheffler. Very like-minded near-contemporaries, such as Valentin Weigel (d. 1588), were intensively engaged with Boethius's treatise; Jean Bernaerts produced a Latin edition in Antwerp in 1607; Theodor Sitzmann produced another one in Hanover, and also in 1607; Pedro Bertio produced an edition in Lyon in 1620; this one was followed in 1633 when Petrus Bertius published his edition of Boethius's treatise in Leiden; Ioan. Jan[beta]onium (sic) published one in Amsterdam in 1653; Renatus Vallinus produced an edition in Lyon in 1656; Jean-Antoine Huguetan and René de Ceriziers published a French translation in 1650; Johann Hellwig brought to print a German translation in 1660; and this was followed by Christian Knorr von Rosenroth with another translation in 1667 (Classen, "Valentin Weigel"; Classen, "Boethius and No End in Sight"), to mention only the most influential and most successful editions and translations.

To remind ourselves of a crucial biographical fact, namely: Scheffler himself began with his academic studies in Straßburg in 1643, continued them in Leiden in 1644 for the duration of two years, and then transferred to Padua in 1647, where he received his doctorate in medicine and philosophy (!) on 25 September 1647 (Held 1952, vol. 1, pp. 20-24), that is, at a time when intellectual Europe was abuzz with this famous Latin text from late antiquity once again. His teachers confirmed that he was extraordinarily intelligent and motivated in his studies (Held 1952, vol. 1, p. 20), so it does not come as a surprise that the future poet Scheffler responded in kind, and infused many of his epigrams with Boethian ideas. Of course, his primary goal was always to explore deeply Christian concepts about the relationship between the self and God, but we are not far off the mark when we identify Boethius as a critical source for Scheffler's philosophical ruminations.

While the epigrams reflect numerous echoes of and parallel ideas in this late antique treatise on the logical quest for human happiness, they do not outline, naturally, a holistic program based on Boethius. Nevertheless, as epigrams, which, by definition only intend to present sudden thoughts, insights, perceptions, or epiphanic realizations in the briefest possible terms (Mohr 2007), they document, in a variety of intriguing ways, how much Boethius's thoughts were commonly present in European literature (Watanabe-O'Kelly 2013). Thus, when we take together the external-bibliographical data - and the internal-literary-analytic—evidence, we are in a very solid position to recognize, in Scheffler, a highly learned and also religiously devout poet of the Baroque era, who continued the extensive engagement with this late antique philosophy by way of incorporating some of his essential ideas into his mystico-literary reflections.

Funding: This research received no external funding.

Conflicts of Interest: The author declares no conflict of interest.

\section{References and Notes}

Althaus, Horst. 1956. Johann Schefflers "Cherubinischer Wandersmann": Mystik und Dichtung. Beiträge zur deutschen Philologie. Gießen: Wilhelm Schmitz Verlag, vol. 9.

Angelus, Silesius. 1949. Cherubinische Wandersmann: Sinnliche Beschreibung der vier letzten Dinge. Angelus Silesius, Sämtliche poetische Werke. Munich: Carl Hanser Verlag, vol. 3. 
Auerbach, Erich. 1953/1968. Mimesis: The Representation of Reality in Western Literature. Translated by Willard R. Trask. Princeton: Princeton University Press. First published 1946. (In German)

Bassnett, Susan, ed. 2019. Translation and World Literature. New Perspectives in Translation and Interpreting Studies. London and New York: Routledge.

Beecroft, Alexander. 2015. An Ecology of World Literature: From Antiquity to the Present Day. London and Brooklyn: Verso.

Boethius, Anicius Manlius Severinus. 1976. De consolatione philosophiae: Libri quinque; quos denuo recognovit adnotationibus illustravit adiectis apparatu critico bibliographia indicibus biblico et al. ageriano Adrianus a Forti Scuto. opus mortuo auctore edendum curavit Georgius D. Smith. Rpt. Hildesheim and New York: Olms. First published 1925.

Boethius, Anicius Manlius Severinus. 2005. De consolatione philosophiae, 2nd ed. Edited by Claudio Moreschini. Bibliotheca scriptorvm Graecorvm et Romanorvm Tevbneriana. Munich: Saur. First published 2000.

Boethius, Anicius Manlius Severinus. 2001. Consolation of Philosophy. Translated by Joel C. Relihan. Indianapolis and Cambridge: Hackett Publishing.

Borsò, Vittoriam, and Schamma Schahadat, eds. 2019. Grundthemen der Literaturwissenschaft: Weltliteratur. Berlin and Boston: Walter de Gruyter.

Classen, Albrecht. 2018. Boethius and No End in Sight: The Impact of De consolatione philosophiae on Early Modern German Literature from the Fifteenth Through the Seventeenth Century: Andreas Gryphius and Johann Scheffler (Angelus Silesius). Daphnis 46: 448-66. [CrossRef]

Classen, Albrecht. 2019. Valentin Weigel and Boethius: Mystical-Philosophical Concepts in Late Sixteenth-Century Protestant Thinking. To appear in Carmina Philosophiae.

Courcell, Pierre. 1967. La Consolation de Philosophie dans la tradition littéraire. Paris: Études Augustiniennes.

Cremer, Desiree. 2015. Boethius französisch zur diskursiven Vernetzung mittelalterlicher und frühneuzeitlicher Consolatio-Übersetzungen. Analecta romanica, 85. Frankfurt am Main: Vittorio Klostermann.

Curtius, Ernst Robert. 1989/1990. European Literature and the Latin Middle Ages. Bollingen Series, XXXVI; Translated by Willard R. Trask. Princeton: Princeton University Press. First published 1948. (In German)

Damrosch, David. 2017. How to Read World Literature, 2nd ed. New York: John Wiley \& Sons. First published 2009.

Egawa, Hideaki. 1992. Die Wanderung eines cherubinischen Dichters: Angelus Silesius. Doitsu Bungaku Ronko 34: $37-51$.

Eickelmann, Manfred, and Udo Friedrich, eds. 2013. Praktiken europäischer Traditionsbildung im Mittelalter: Wissen-Literatur-Mythos. Berlin: Akademie Verlag.

Eilert, Edit. 1936. Angelus Silesius als Streittheologe seiner Zeit. Dresden: Dilkert.

Fang, Weigui, ed. 2018. Tensions in World Literature: Between the Local and the Universal. Singapore: Springer.

Translated by J. E. Crawford Flitch. 1932, Angelus Silesius. In Selections from The Cherubinic Wanderer. The Hyperion Library of World Literature. Westport: Hyperion Press.

Translated by Frederick Franck. 2005, Messenger of the Heart: The Book of Angelus Silesius with Observations by the Ancient Zen Masters. Bloomington: World Wisdom.

Gebert, Bent. 2012. Technik und Ereignis: 'Gelassenheit' in Johannes Schefflers 'Cherubinischem Wandersmann'. In Semantik der Gelassenheit: Generierung, Etablierung, Transformation. Edited by Burkhard Hasebrink and Historische Semantik. 17. Göttingen: Vandenhoeck \& Ruprecht, pp. 288-319.

Gibson, Margaret, ed. 1981. Boethius: His Life, Thought and Influence. Oxford: Basil Blackwell.

Gramling, David. 2016. The Invention of Monolingualism. New York: Bloomsbury Publishing.

Hackett, Jeremiah M., ed. 2013. A Companion to Meister Eckhart. Brill's Companions to the Christian Tradition, 36. Leiden and Boston: Brill.

Held, Hans Ludwig, ed. 1952. Angelus Silesius: Die Geschichte seines Lebens und seiner Werke: Urkunden. Angelus Silesius, Sämtliche poetische Werke, 1. Munich: Carl Hanser Verlag.

Hess, Peter. 1989. Epigramm. Sammlung Metzler, 248. Stuttgart: Metzler.

Hess, Peter. 2007. Poetry in Germany, 1450-1700. In Early Modern German Literature 1350-1700. Edited by Max Reinhart. Camden House History of German Literature, 4. Rochester: Camden House, pp. 395-465.

Hoffmann, Martin. 2008. Angelus Silesius: seine Thesen in heutiger Sicht und Bedeutung. Karlsruhe: Helmesverlag. Holzberg, Niklas. 2012. Martial und das antike Epigramm, 2nd ed. Darmstadt: Wissenschaftliche Buchgesellschaft. 
Huss, Bernhard, and David Nelting, eds. 2017. Schriftsinn und Epochalität: Zur historischen Prägnanz allegorischer und symbolischer Sinnstiftung. Germanisch-Romanische Monatsschrift, Beihefte, 81. Heidelberg: Universitätsverlag Winter.

Kaylor, Noel Harold, Jr., and Philip Edward Phillips, eds. 2012. A Companion to Boethius in the Middle Ages. Brill's Companions to the Christian Tradition. Leiden and Boston: Brill.

Kaylor, Noel Harold, Jr., and Philip Edward Phillips. 2016. Vernacular Traditions of Boethius's De Consolatione philosophiae. Edited by Research in Medieval Culture. Kalamazoo: Medieval Institute Publications, Western Michigan University.

Kern, Franz. 1866. Johann Scheffler's Cherubinische Wandersmann: Eine literarhistorische Untersuchung. Leipzig: S. Hirzel.

McInerny, Ralph. 1992. Boethius. In Medieval Philosophers. Edited by Jeremiah Hackett. Dictionary of Literary Biography, 115. Detroit and London: Gale Research, pp. 110-17.

Mohr, Jan. 2007. Epigramm und Aphorismus im Verbund: Kompositionen aus kleinen Textformen im 17. und 18. Jahrhundert (Daniel Czepko, Angelus Silesius, Friedrich Schlegel, Novalis). Mikrokosmos, 78. Frankfurt am Main: Peter Lang.

Moran, Dermot. 2013. Meister Eckhart in 20th-Century Philosophy. In A Companion to Meister Eckhart. Edited by Jeremiah M. Hackett. Brill's Companions to the Christian Tradition, 36. Leiden and Boston: Brill, pp. 669-98.

Prendergast, Christopher, ed. 2004. Debating World Literature. London: Verso.

Reichert, Ernst Otto. 1967. Johannes Scheffler als Streittheologe: Dargestellt an dem konfessionspolemischen Traktaten der "Ecclesiologia". Studien zu Religion, Geschichte und Geisteswissenschaft, 4. Gütersloh: Mohn.

Sammons, Jeffrey L. 1967. Angelus Silesius. Twayne's World Authors Series, 25; New York: Twayne.

Sammons, Jeffrey L. 1996. Johann Scheffler (Angelus Silesius). In German Baroque Writers, 1580-1660. Edited by James Hardin. Dictionary of Literary Biography, 164. Detroit, Washington and London: Gale Research, pp. 279-88.

Scheffler, Johann. 1949. See Angelus (1949).

Schmidt, Josef. 1986. Angelus Silesius. In The Cherubinic Wanderer. Translated and foreword by Maria Shrady. New York, Mahwah and Toronto: Paulist Press.

Schweitzer, Christoph E. 1992. Das literarische Nachleben von Johannes Schefflers “Cherubinischen Wandersmann". In Der Buchstab tödt-Der Geist macht lebendig: Festschrift zum 60. Geburtstag von Hans-Gert Roloff von Freunden, Schülern und Kollegen. Edited by James Hardin and Jörg Jungmayr. Bern, Berlin and Frankfurt am Main: Peter Lang, vol. I, pp. 799-812.

Spörri, Elisabeth. 1947. Der Cherubinische Wandersmann als Kunstwerk. Zürcher Beiträge zur deutschen Sprachund Stilgeschichte, 2. Zürich: Atlantis Verlag.

Stenger, Georg. 1990. Ohne Warum: Versuch einer Phänomenologie des Ungrundes im Anschluss an den "Cherubinischen Wandersmann" von Angelus Silesius. Kleine Arbeiten zur Philosophie, 23. Essen: Verlag Die Blaue Eule.

Tötösy de Zepetnek, Steven, and Tutun Mukherjee, eds. 2013. Companion to Comparative Literature, World Literatures, and Comparative Cultural Studies. New Delhi: Cambridge University Press India.

Vipper, Yuri B. 1985. National Literary History in History of World Literature: Theoretical Principles of Treatment. New Literary History 16: 545-58. [CrossRef]

Von Kralik, Richard. 2013. Angelus Silesius und die christliche Mystik. Paderborn: Salzwasser Verlag.

Watanabe-O'Kelly, Helen. 2013. Ways of Knowing: Blaise Pascal, Angelus Silesius and Catharina Regina von Greiffenberg. In The Present Word: Culture, Society and the Site of Literature: Essays in Honour of Nicholas Boyle. Legenda Main Series; Edited by John Walker. Leeds: Legenda, pp. 92-101.

Weisstein, Ulrich. 1973. Comparative Literature and Literary Theory. Translated by William Roggan. Bloomingon and London: Indiana University Press. First published 1968.

Weisz, Jutta. 1979. Das deutsche Epigramm des 17. Jahrhunderts. Germanistische Abhandlungen, 49. Stuttgart: Metzler.

(C) 2018 by the author. Licensee MDPI, Basel, Switzerland. This article is an open access article distributed under the terms and conditions of the Creative Commons Attribution (CC BY) license (http:/ / creativecommons.org/licenses/by/4.0/). 